\title{
20. PALEOENVIRONMENTAL HISTORY OF THE WALVIS RIDGE AT THE CRETACEOUS- TERTIARY TRANSITION, FROM MINERALOGICAL AND GEOCHEMICAL INVESTIGATIONS ${ }^{1}$
}

\author{
Hervé Chamley and Henri Maillot, Sédimentologie et Géochimie, E.R.A. 764, Université de Lille I, 59655 \\ Villeneuve D'Ascq Cedex, France \\ Gérard Duée, Géologie, E.R.A. 764, Université de Pau, 64000, Pau, France \\ and \\ Christian Robert, Géologie Marine, LA 41, Université de Luminy, 13288 Marseille Cedex 2, France.
}

\begin{abstract}
Detailed studies on clay mineralogy and inorganic geochemistry performed on late Campanian to late Paleocene sediments of DSDP Sites 525, 527, 528, and 529 provide paleoenvironmental information about the CretaceousTertiary transition in the Walvis Ridge area. They suggest (1) the existence of an average hot and humidity-contrasted climate on adjacent land masses, favoring the development of coastal areas with poorly drained soils (smectites) and the formation during the Paleocene of peri-marine confined basins (palygorskite); (2) the importance during the Late Cretaceous of local volcanic supply at the shallowest site (525), of distant terrigenous supply at the deepest site (527), and western migration of the spreading center; (3) the occurrence during the late Maestrichtian of three tectonic phases on the African margin, suggested by a strong illite supply and attributed to a major stage of seafloor spreading; and (4) a marked change in the mineralogy at the Maestrichtian/Paleocene boundary (smectite increase), indicative of tectonic relaxation and possibly local volcanic activity, preceding the subsidence of the Walvis Ridge and the development of deep-water circulation.
\end{abstract}

\section{INTRODUCTION}

Four sites were drilled during Leg 74 across the Walvis Ridge, on a structural block trending toward the Angola Basin (Fig. 1). The sites, located along a SE-NW transect, are as follows (from shallowest to deepest) (see site chapters, this volume):

\begin{tabular}{cccc}
\hline Site & Latitude; Longitude & $\begin{array}{c}\text { Water Depth } \\
(\mathrm{m})\end{array}$ & $\begin{array}{c}\text { Penetration } \\
(\mathrm{m})\end{array}$ \\
\hline 525 & $29^{\circ} 04.24^{\prime} \mathrm{S} ; 02^{\circ} 52.12^{\prime} \mathrm{E}$ & 2467 & 678 \\
529 & $28^{\circ} 55.83^{\prime} \mathrm{S} ; 02^{\circ} 46.08^{\prime} \mathrm{E}$ & 3035 & 417 \\
528 & $28^{\circ} 31.49^{\prime} \mathrm{S} ; 02^{\circ} 19.44^{\prime} \mathrm{E}$ & 3800 & 555 \\
527 & $28^{\circ} 02.49^{\prime} \mathrm{S} ; 01^{\circ} 45.80^{\prime} \mathrm{E}$ & 4428 & 384.5 \\
\hline
\end{tabular}

The four holes that penetrated Upper Cretaceous sediments provided excellent recovery of the CretaceousTertiary transition. Basement rocks consist of oceanic basalts at Sites 525, 528 and 527, interbedded with limestone, chalk, mudstone, claystone, or chert often resedimented and mixed with volcaniclastic debris. The oldest sediments are late Campanian at Site 525 and middle to late Maestrichtian at the other sites; they consist chiefly of marly chalks and bioturbated marls and are more sandy toward the bottom of the holes (Fig. 1). Sediments become more calcareous upward. The lower Paleocene section contains mainly pelagic chalks and calcareous oozes, often interrupted by slumps, especially at the Maestrichtian/Paleocene boundary, where reddish deposits occur.

\footnotetext{
${ }^{1}$ Moore, T. C., Jr., Rabinowitz, P. D., et al., Init. Repts. DSDP, 74: Washington (U.S. Govt. Printing Office).
}

The purpose of the present study is to add to the paleoenvironmental interpretations of the Cretaceous/ Tertiary boundary through investigations of clay mineralogy and inorganic bulk geochemistry. We studied 115 sediment samples from late Campanian to late Paleocene in age, most of them late Maestrichtian and early Paleocene. The major results presented in this chapter concern the clay mineralogy across the Cretaceous/Tertiary boundary. Detailed geochemical data and routine mineralogical results relative to the whole stratigraphic column are given in the general chapter by Maillot and Robert (this volume).

\section{METHODS}

All samples were submitted to X-ray diffraction analysis on oriented pastes of carbonate-free sediment particles smaller than $2 \mu \mathrm{m}$. The methods used for qualitative and semiquantitative determinations are those presented by Chamley (1980). About $20 \%$ of the samples were observed by transmission electron microscopy on fractions smaller than $8 \mu \mathrm{m}$. Geochemical analyses of major and trace elements were done by atomic and molecular absorption spectrometry, according to the methods summarized by Robert and Maillot (in press).

Specific geochemical index parameters were used in order to determine the volcanic, oceanic, and terrigenous influences on sedimentation. The most important indices employed here are

$$
\mathrm{Mn}^{*}=\log \frac{\text { Mn sample }}{\text { Mn shales }} / \frac{\text { Fe sample }}{\text { Fe shales }} \text { (Boström et al., 1972). }
$$

The variation in $\mathrm{Mn}^{*}$ values reflects the intensity and vicinity of volcanic influences in a marine environment and depends on the $\mathrm{Fe}$ and $\mathrm{Mn}$ precipitation in oxidized conditions. Sediments located very close to a submarine rift are characterized by high contents of $\mathrm{Fe}$ and low $\mathrm{Mn}^{*}$ values. When the spreading center moves progressively away from the site area, $\mathrm{Mn}^{*}$ values strongly increase and then decrease, in the same way as the absolute Mn content (Maillot and Robert, 1980).

$$
\mathrm{D}^{*}=\frac{\mathrm{Al}}{\mathrm{Al}+\mathrm{Fe}+\mathrm{Mn}} \quad \text { (Boström et al., 1969). }
$$



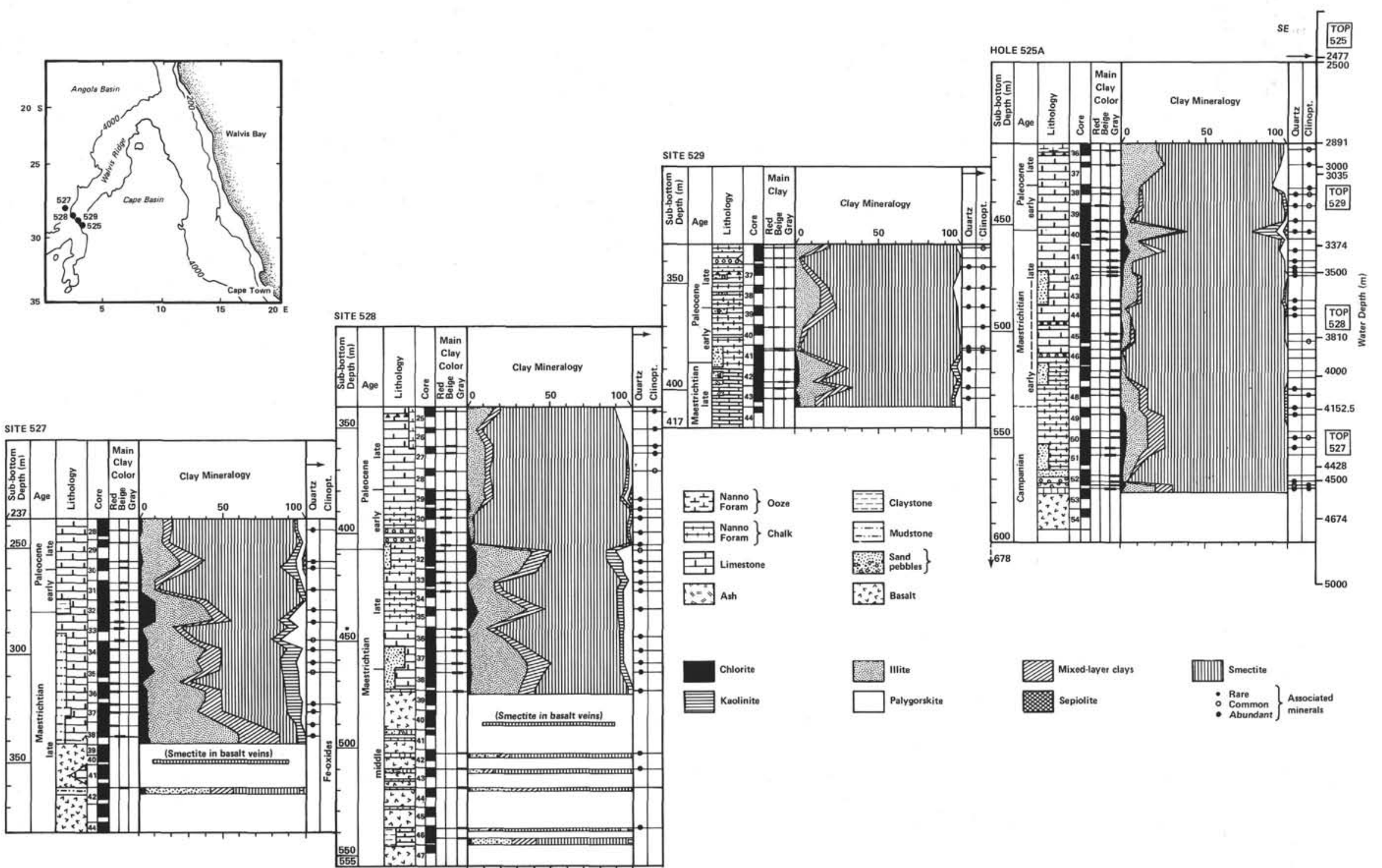

Figure 1. Site location map and clay mineralogy at the Cretaceous-Tertiary transition. 
D* increases when the terrigenous influences predominate and generally varies inversely with $\mathrm{Mn}^{*}$.

Other environmental influences can modify the $\mathrm{Mn}^{*}$ and $\mathrm{D}^{*}$ values. For instance, the appearance and development of deep currents favor the oxidation and precipitation of dissolved $\mathrm{Mn}$. In clay-rich sediments, an increase of kaolinite can cause an increase of $\mathrm{D}^{*}$, and a strong supply of $\mathrm{Fe}$-smectites can cause a decrease of $\mathrm{Mn}^{*}$, independent of changes in terrigenous or volcanic supplies. Similarly an increase in sedimentation rate can cause a dilution of metalliferous elements. It is necessary to take each of the features into account in order to decipher the significance of variations in the geochemical indices.

\section{RESULTS}

The clay mineralogy of uppermost Mesozoic and lowermost Cenozoic sediments is very diversified (Fig. 1). Smectite occurs as the most common species, accompanied by variable but locally important amounts of chlorite, illite, irregular mixed-layer clays (chiefly illite-smectite and chlorite-smectite types), kaolinite, palygorskite, and sepiolite. Associated minerals include quartz, feldspars, clinoptilolite, opal CT, goethite, and subamorphousiron oxides. These clay assemblages are common at the Cretaceous/Tertiary boundary in the Atlantic (Chamley and Robert, 1979). There is no relationship among the clay mineralogy, the lithology, the petrography, or the depth of burial. Clay materials are considered to be essentially inherited from land masses, as in the case of most of Mesozoic and Cenozoic Atlantic environments, and this is confirmed by geochemical investigations (Chamley, 1979; Debrabant and Foulon, 1979; Robert et al., 1979; Maillot, 1980; Maillot and Robert, 1980). In spite of the proximity of the four sites (maximum $1^{\circ}$ in latitude and longitude), a progressive mineralogical change occurs: in a general way, smectite amounts decrease from the shallowest (525) to the deepest site (527), whereas other clay minerals increase. This points to the importance of local influences on the distributions of clay minerals in the sediments.

The bulk geochemistry expresses the persistence of oxidized bottom conditions through time, indicated by rather high contents of $\mathrm{Mn}$ and $\mathrm{Fe}$ ( $\mathrm{Mn}^{*}$ values). The amount of $\mathrm{Sr}$ compared to $\mathrm{Ca}$, indicative of paleodepths relative to the CCD (Robert and Maillot, in press), suggests that all four sites have been subsiding since the Late Cretaceous, with the major phase of subsidence occurring during the late Paleocene and the middle Eocene (Maillot and Robert, this vol.). Terrigenous influences remained important throughout this time ( $\mathrm{D}^{*}$ values), with maximum $\mathrm{D}^{*}$ values occurring close to the Cretaceous/Tertiary boundary and minimal values occurring during the Late Cretaceous, when volcanic influences were noticeable.

\section{BASALTS AND INTERBEDDED SEDIMENTS}

Some basalt veins show a minor alteration and clay fill which consists essentially of highly crystallized smectite associated with feldspars. On the other hand, the sedimentary intercalations contain, in addition to diversely crystallized smectites, various amount of illite (5-45\% of clay minerals), irregular mixed-layer clays $(5-20 \%)$, chlorite $(0-5 \%)$, kaolinite $(0-10 \%)$, and palygorskite $(0-5 \%)$ associated with feldspars and frequent quartz. The absence of correlations between the miner- alogy of the basalts and sediments indicates that a large part of the sedimentary minerals does not derive from local, volcanogenic sources but from more distant, terrigenous ones.

\section{SEDIMENTS IMMEDIATELY OVERLYING THE UPPERMOST BASALTS}

As in the underlying deposits, the clay mineralogy of Campanian to late Maestrichtian sediments, deposited just above the uppermost basalts, is very diversified and is consistent with an extravolcanic source. In spite of closeness of the different sites, the large dispersal power of clays gives rise to large mineralogical differences from the southeast to the northwest (Figs. 1 and 2): smectite, very abundant and highly crystallized at the shallowest Site 525, decreases progressively toward Site 527 , whereas the abundance of other minerals, especially illite, increases.

The morphology of smectite at Site 525 shows large bundles of long sheets (Plate 1, A and B), frequent in volcanogenic materials (Chamley and Bonnot-Courtois, 1981). At Site 527 smectite shows common sheets with blurred contours and is accompanied by primary minerals (illite, chlorite), fibers of palygorskite, and some kaolinite hexagons (Plate 1, C and D). Sites 529 and 528 show intermediate clay assemblages.

Thus mineralogical investigations indicate an abundance of smectite, a mineral usually favored in deep and hydrodynamically quiet zones, in the shallower area and an abundance of typical terrigenous species (illite, chlorite) in the deeper area farther from the African sources. This apparent contradiction is explained by the differing modalities of the volcanic record from late Campanian to late Maestrichtian (Fig. 3):

1) Close to Site 525 , volcanics were produced in subaerial conditions (Moore and Rabinowitz, this volume). Such conditions favored the leaching of rocks and the rapid, intense alteration of basalts into smectite clay, especially with the warm climate and sharp contrasts in humidity prevailing during the Late Cretaceous (Maillot and Robert, 1980). As a result, volcanogenic smectites

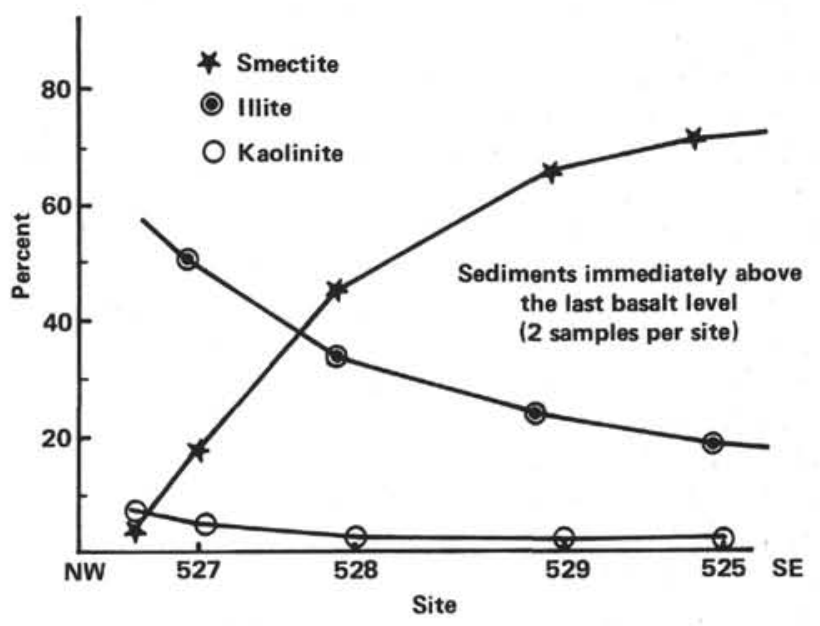

Figure 2. Clay mineralogy of sediments overlying the uppermost basalts. 

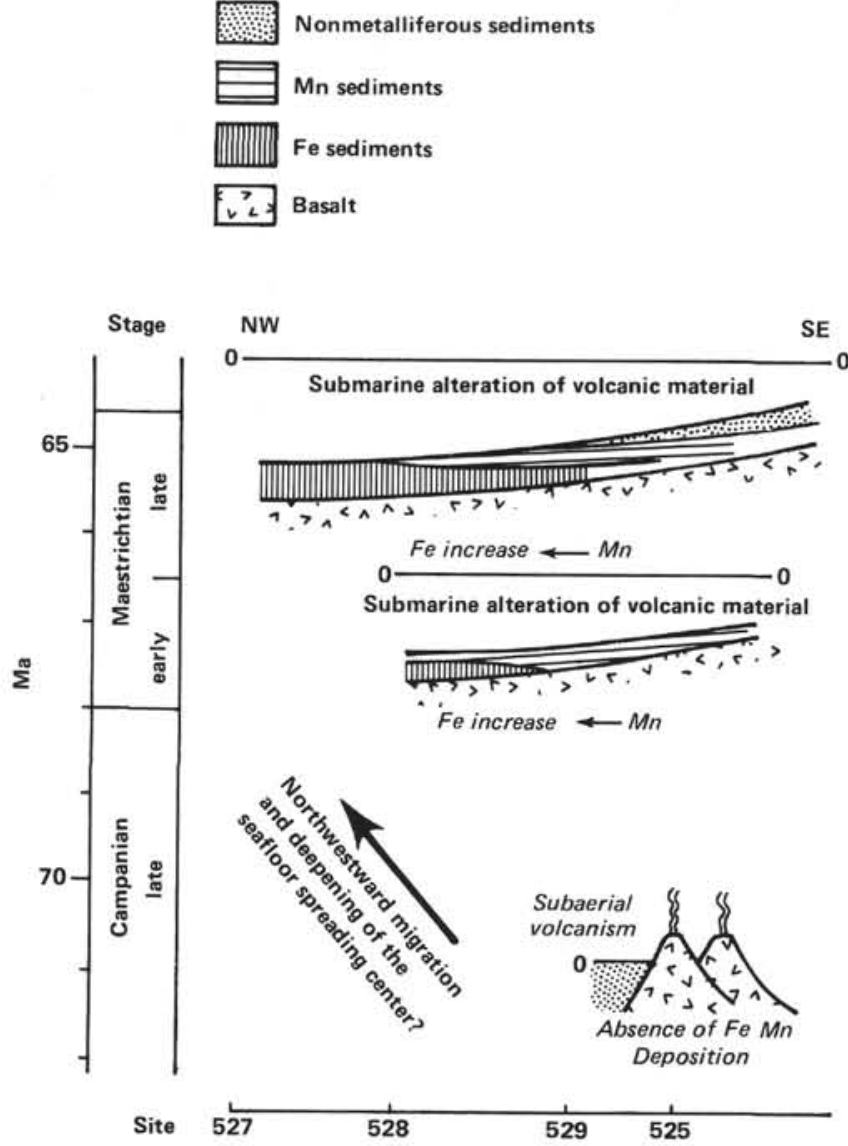

Figure 3. Late Cretaceous $\mathrm{Fe}$ and $\mathrm{Mn}$ contents (in italic type) interpretation (in roman type).

eroded from subaerial volcanoes were probably supplied in great amounts in the area of Site 525, diluting the more distant detrital input.

2) Close to Site 527 , volcanic rocks were produced in submarine conditions, possibly caused by the deepening and migration of the seafloor spreading center (Moore and Rabinowitz, this volume). Such conditions led to little alteration of submarine basalts (little smectite), and permitted the distant detrital clay background (illite and other species) to be clearly and dominantly expressed in the marine sedimentation.

3) At Sites 529 and 528 conditions were intermediate, and the clay mineralogy expresses the progressive northward transition from local volcanogenic supply to general detrital supply.

Such an interpretation is supported largely by geochemical data (Fig. 3 and Maillot and Robert, this volume). At Site 525 metal concentrations are low $\left(\mathrm{Fe}_{2} \mathrm{O}_{3}=\right.$ $3 \%$; $\mathrm{Mn}=1000 \mathrm{ppm}$ ), as are the values of the parameters $\mathrm{Mn}^{*}(0.33)$ and $\mathrm{D}^{*}(0.54)$. Such results in a context of volcanic activity can be explained by a subaerial alteration of basalts: weathering products such as $\mathrm{Fe}$ and $\mathrm{Mn}$ are predominantly precipitated on land before reaching the ocean and therefore are not abundant in the marine sediments. On the other hand, at Sites 528, 529, and 527 , values of $\mathrm{Fe}$ and $\mathrm{Mn}$ are higher, suggesting the existence of a submarine volcanic environment.

\section{LATE CAMPANIAN AND EARLY MAESTRICHTIAN}

Late Campanian and early Maestrichtian sediments, present at Site 525 only, show noticeable changes in their clay minerals content, although smectite remains the dominant species (Fig. 1). Most changes occur in the turbidite sequences of Core 525A-52. Considering the high abundance and crystallinity of smectite and the proximity of basalts produced under subaerial conditions, a volcanic influence on clay mineralogy is highly probable. But there is no close relationships between the clay mineralogy and the presence of volcanic glass or palagonite. For instance the clay fraction of Cores 44 to 47 in Hole $525 \mathrm{~A}$ is consistently 95 to $100 \%$ smectite, whereas the volcanic debris is present in highly variable amounts (traces to 95\%) and does not show significant alteration. Therefore it is difficult to determine which parts of the smectite fraction have a yolcanic subaerial origin and which a volcanic submarine or simply pedogenic origin.

\section{LATE MAESTRICHTIAN}

Globally, the clay distribution is similar to that identified in the early Maestrichtian (Fig. 1), suggesting the permanence of local volcanic influence at Site 525 and of distant terrigenous influences increasing toward the $N W$ (Site 527). The geochemical data (Maillot and Robert, this volume) indicate that the relative paleodepths among the sites have remained unchanged during the Late Cretaceous and Cenozoic. Moreover, the geochemistry suggests the persistence of subaerial volcanism at Site 525. At Site $528 \mathrm{Fe}_{2} \mathrm{O}_{3}$ was abundant during the middle Maestrichtian $(4.50 \%$ ) and decreased during the late Maestrichtian (3\%), whereas $\mathrm{Mn}$ and $\mathrm{Mn}^{*}$ increased (from 2000 to $2700 \mathrm{ppm}$ and from 0.68 to 1.00 , respectively): This evolution reflects the removal of the site area from a spreading center, in a submarine volcanic environment (Fig. 3). At Site 527 the clay fraction is especially abundant (about $30 \%$ of the sediments), and the presence in noticeable amounts of structural $\mathrm{Fe}$ and $\mathrm{Mn}$ prevents the geochemical expression of metals associated with the minerals.

The detailed clay mineralogy of late Maestrichtian sediments shows the presence of three sharp "illite peaks" alternating with abundant smectite at each site except Site 529, in which only the uppermost Maestrichtian was recovered (Fig. 1). Illite is accompanied by noticeable amounts of chlorite and irregular mixed-layer clays and by some kaolinite, palygorskite, quartz, or feldspars. In the Atlantic Ocean, Late Cretaceous (from late Santonian to late Maestrichtian) and early Paleocene sediments are characterized by diverse clay mineralogy, marked in particular by a strong decrease of smectite and an increase of illite content (Chamley and Robert, 1979; Giblin, 1979). This was discussed and attributed chiefly to the tectonic activity of Atlantic margins induced by a major stage of seafloor spreading, with a simultaneous development of deep-water mass exchanges and eustatic movements. This paleogeographic event appears to take place in several subphases (Fig. 9), which 
are clearly expressed by the clay mineralogy where sampling is dense. It is not clear if the sub-phases have only local significance or are global. Other subphases of the same event appear during the late Campanian-early Maestrichtian (Site 525) and the early Paleocene (Fig. 1) and seem to be connected with the volcanotectonic history of the Walvis Ridge and the Mid-Atlantic Ridge (see Shaffer, in press). Note that sea level changes could also play a role in bringing about some of the mineralogical events identified here.

\section{MAESTRICHTIAN-PALEOCENE BOUNDARY}

A major change occurs in the clay stratigraphy at the passage from Upper Cretaceous to lower Paleogene. At all four sites the smectite content of the clay fraction strongly increases in the lowermost Paleocene sediments, whereas the abundance of all other clay minerals decreases. This change is clearly expressed by the X-ray diffraction data, in reference to the general data (Figs. 1 and 4) and to the abundance of smectite relative to the sum of other species (Fig. 5). The same change appears on electromicrographs: blurred sheets of smectite predominate in lower Paleocene sediments (Plate 2, A and B), and upper Maestrichtian clays include various species such as sharp-edged illite and chlorite, short fibers of detrital palygorskite, blurred particles of smectite and irregular mixed-layered clays, and some kaolinite hexagons (Plate $2, C$ and D). We find no evidence that such a major clay mineralogical change has been described in earlier studies, probably because of the rather rare recovery of good Cretaceous-Tertiary transition material in DSDP sites, the general lack of detailed sampling, or the confinement of the phenomenon to the area at hand. There is no evidence of a catastrophic event (cf. Hsü, 1980) giving rise to the change in clay mineralogy; the nature and relative abundance of minerals are consistent with the period and area and are not accompanied by important geochemical changes (Maillot and Robert, this volume). If a catastrophic event did occur, its effects could not have lasted long enough to influence the alteration and pedogenic processes.

The magnitude of the smectite increase differs significantly from Site 527 (NW) to Site 525 (SE), depending on the time interval:

1) In the broad interval, corresponding to the entire late Maestrichtian and early Paleocene, the mineralogical change is important at Site 527 (and less so at nearby Site 528) and weak at Site 525 (Figs. 5 and 6). Site 527 is the deepest one, and its clay sedimentation is considered to be controlled chiefly by distant detrital supply from various African sources (see the foregoing). It is therefore likely that the large-scale clay change recorded at Site 527 depends mainly on a general paleogeographic event. The major cause could be a tectonic relaxation of adjacent land masses, favoring peneplanation and the development of $\mathrm{Fe}$-Al smectite in poorly drained continental soils which are then eroded and transported to the marine environment (Fig. 9). Such a morphological evolution of land-masses, probably linked to a transgressive regime and to subsidence movements (Vail et al., 1977), is consistent with the quiet, regular, pelagic marine sedimenta-
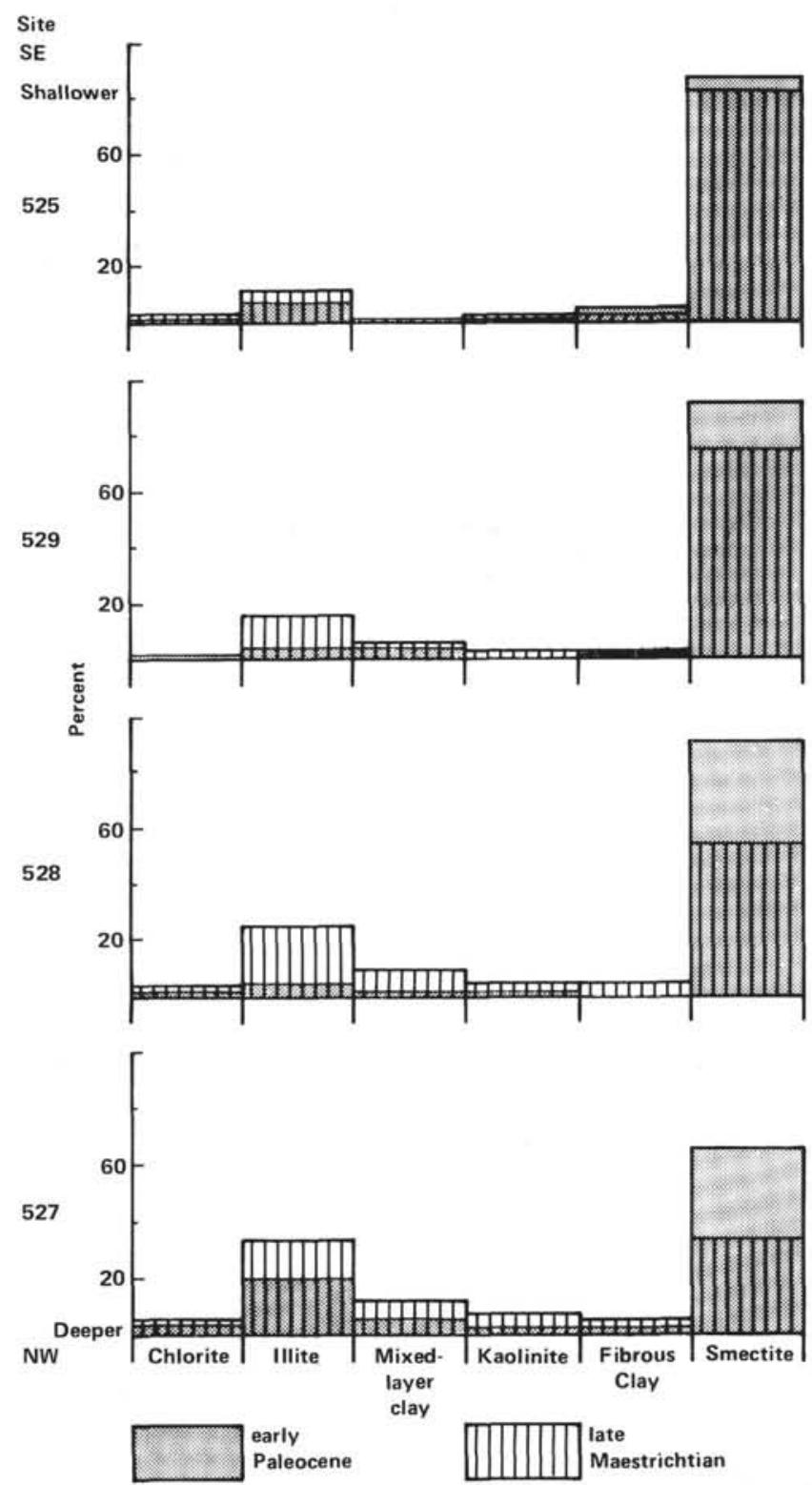

Figure 4. Average clay minerals contents during the late Maestrichtian and early Paleocene.

tion indicated by the decrease of resedimentation structures and the development of chalks and calcareous oozes (site chapters, this volume). Similar events occur on the Rio Grande Rise at the same period (Robert, 1981).

Some geochemical data argue for the development of continental smectitic soils during the early Paleocene. At Sites 527 and 528, the uppermost Maestrichtian shows low $\mathrm{Fe}$ contents as revealed by the abundance of illite and other non-smectitic clays. The presence of abundant smectite in the lower Paleocene corresponds to fairly high contents of $\mathrm{Fe}$, an augmentation of the global detrital influence (decrease of $\mathrm{Mn}^{*}$, increase of $\mathrm{D}^{*}$ ), and an Fe-Al smectite composition (intermediate between beidellite and nontronite (cf. Deer et al., 1962; Debrabant and Foulon, 1979) (Fig. 7). Such a geochemistry is consistent with a predominantly terrigenous soil contribution to the marine clay sedimentation. 


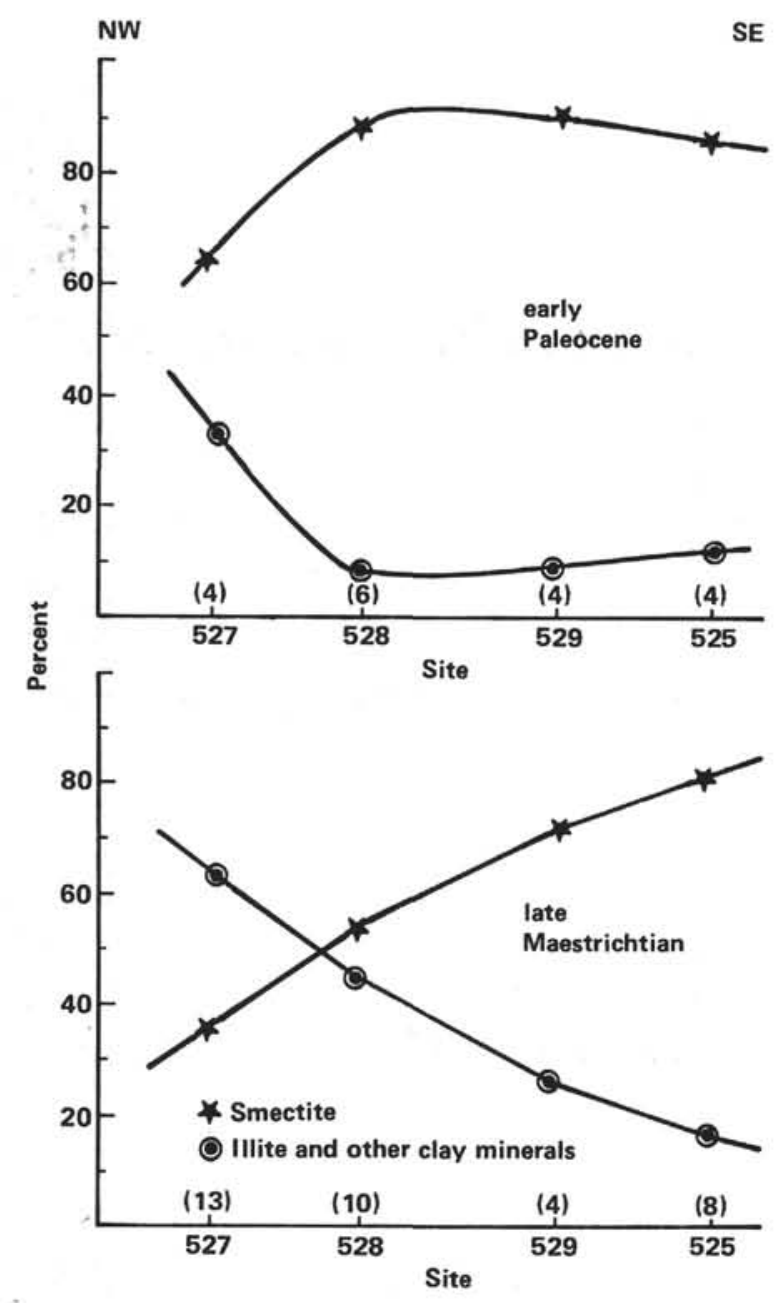

Figure 5. Distribution of smectite and other clay minerals in late Maestrichtian and early Paleocene sediments. (Number of samples taken are given in parentheses.)

2) Over a short interval, corresponding exactly to the Maestrichtian/Paleocene boundary, the mineralogical change is important at Site $\mathbf{5 2 5}$ (and also at nearby Site 529) and weaker at Site 527 (Fig. 8). Site 525 is the shallowest, and during the Late Cretaceous received a primarily local clay supply dominated by volcanogenic materials (see the foregoing). The strong, short mineralogical variation identified at Site 525 may therefore be the result of local paleogeographic changes. The main cause could be a short resurgence of volcanic activity associated with tectonic instability, followed by subsidence and resedimentation (Fig. 9). The abundant supply of smectite would then result mainly from the production and/or reworking of alteration materials issued from the subaerial volcanoes close to Site 525 before they were completely submerged. This interpretation is supported by the abundance of slumps and other resedimentation structures at the Maestrichtian/Paleocene boundary (site chapters, this volume). Moreover, the strong decrease of the detrital influence expressed by the geochemical parameter $\mathrm{D}^{*}$ in the upper Paleocene sediments supports the hypothesis of the influence of nearby volcanic activity (Fig. 7).

\section{EARLY PALEOCENE AND TRANSITION TO LATE PALEOCENE}

Few changes occur in the clay mineralogy during the Paleocene, and the average assemblages encountered just after the Cretaceous/Tertiary boundary remain little modified until the uppermost Paleocene (Figs. 1 and 6). Smectite is abundant and well crystallized in the clay fraction, suggesting the existence on adjacent land masses of flat coastal morphology, tectonic relaxation, poorly drained soils, and hot climate with contrasts in seasonal humidity. Similar influences characterize the entire Atlantic region during this period (Chamley, 1979; Maillot and Robert, 1980). In the Walvis Ridge area these paleogeographic interpretations are reinforced by the following observations. (1) Smectite is Al-Fe type (Fe beidellite), which characterizes clays formed in downstream continental soils under subarid conditions $(\mathrm{Pa}-$ quet, 1969; Debrabant and Foulon, 1979). (2) Kaolinite, a mineral formed principally in upstream, sloping continental soils, disappears almost entirely, during the $\mathrm{Pa}$ leocene, indicating the lack of distant sources; therefore, there is a preponderance of low terrestrial reliefs. (3) Paleocene lithologies comprise dominant pelagic calcareous facies (site chapters, this volume). The near-absence of resedimentation structures suggests that the submarine morphology is rather stable, with fairly low relief, similar to the continental morphology.

Palygorskite, often associated with sepiolite, was present in noticeable amounts, especially in the late Paleocene. This trend was amplified during the latest Paleocene and the early Eocene (Maillot and Robert, this volume), as is the case during the same period in various other Atlantic regions (Mélières, 1978; Chamley, 1979; Chamley and Robert, 1979). The development of fibrous clays corresponds to a chemical sedimentation in perimarine basins, under transgressive conditions and hot climate with sharp contrasts in humidity (Millot, 1964; Trauth, 1977; Weaver and Beck, 1977). Palygorskite and sepiolite are reworked during subsidence and erosion and resedimented in the open ocean basin as detrital minerals (mainly short fibers dispersed among terrigenous species; Plates 1 and 2; Chamley, 1979; Maillot and Robert, 1980). Clinoptilolite occurs frequently in Paleocene sediments (Fig. 1). This mineral is also widely represented in Late Cretaceous-early Paleogene sediments of the world ocean (Nathan and Flexer, 1977) and is mainly the product of chemical sedimentation or early diagenesis of biogenic silica.

During the Paleocene, smectite content generally increased at Site 527 and the relative content of illite increased at Site 525 (Figs. 1 and 6). Nonsmectitic minerals show a trend opposite to smectite at Site 527 (Fig. 6). The resulting mineral assemblages appear to represent $a$ global homogenization of the marine clays during the late Paleocene, probably because of a major subsidence of the Walvis Ridge that allowed the development of large water mass exchanges and the supply of distant suspended detrital minerals at all sites, not including Site 525 (Fig. 9). Subsidence movements are recognized from mineralogical data elsewhere on the Walvis Ridge 

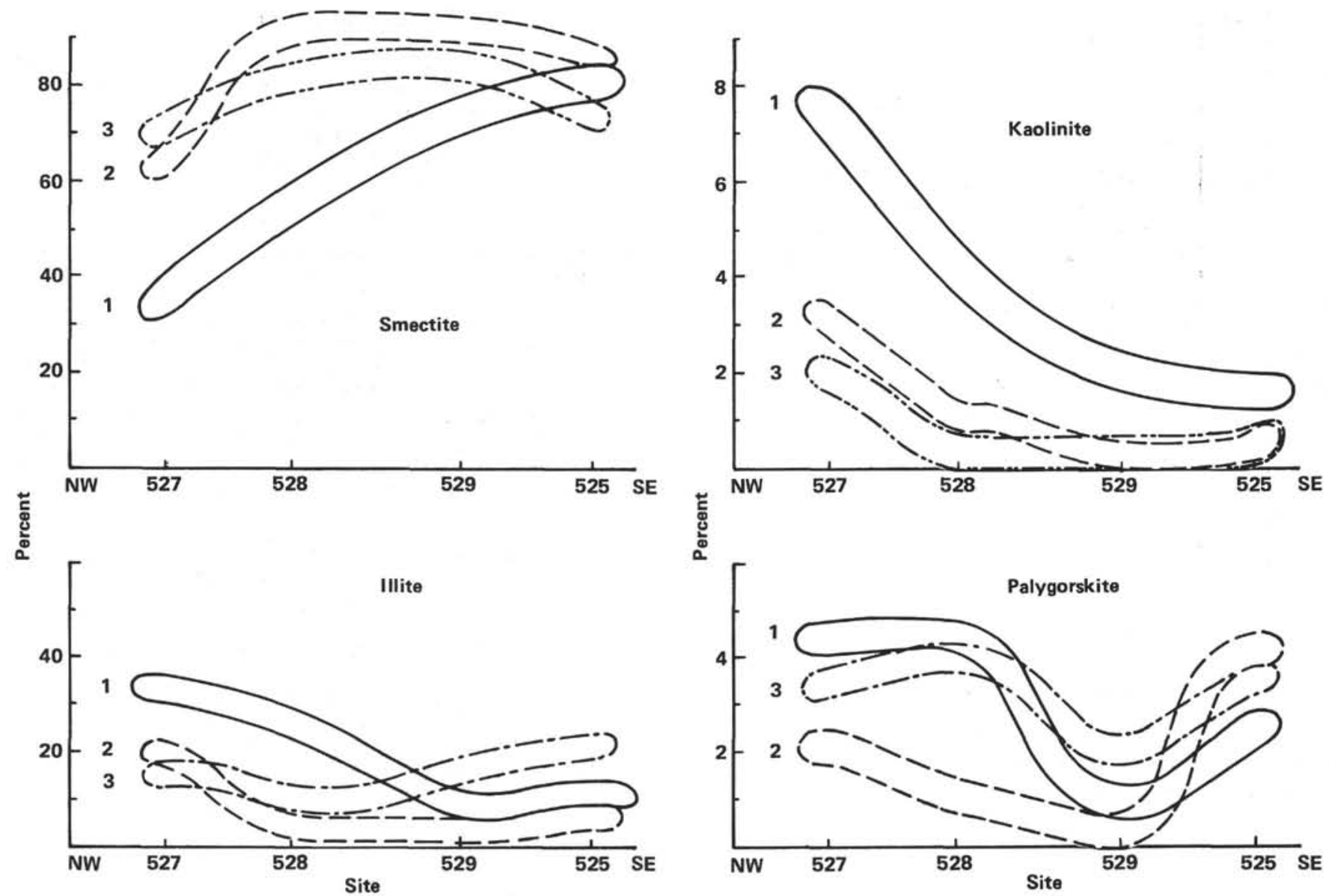

Figure 6. Quantitative variations of the four main clay minerals during the late Maestrichtian and the early Paleocene. $(1=$ late Maestrichtian; $2=$ early Paleocene; 3 = late Paleocene).

(Robert et al., 1979) and resemble those identified on the Rio Grande Rise (Robert, 1981). Geochemical data on $\mathrm{Sr} / \mathrm{Ca}$ ratios, depending on the site location relative to the CCD, agree with this interpretation. Similar subsidence phenomena occur later on, during the middle Eocene (Maillot and Robert, 1980). Note that the relative decrease of smectite at Site 525 could result from its still shallower location compared to the other sites, favoring moderate differential settling processes.

\section{CONCLUSIONS}

The main paleoenvironmental hypotheses, based on mineralogical and geochemical investigations of the Cretaceous-Tertiary transition, are summarized on Figures 3 and 9 . The data most relevant to those hypotheses appear to be the following:

1) The sediments intercalated between oceanic basalts or located immediately above them, as well as most Campanian-Maestrichtian-Paleocene deposits, contain various clay assemblages, whereas basalt alteration is dominated by smectite formation. The lithologic context, mineralogy, morphology, and geochemistry indicate the predominantly detrital character of sedimentary clays.

2) The preponderance of $\mathrm{Fe}-\mathrm{Al}$ smectite in marine sediments suggests the persistence of an average hot climate, with sharp contrasts in humidity, favoring the development of poorly drained soils in coastal continental areas.

3) During the Late Cretaceous, volcanogenic smectite predominated at the shallowest Site 525 , indicating the proximity of strongly weathered, eroded subaerial basalts. Toward the deepest Site 527 there occurs a progressive diversification of the clays. Combined mineralogical and geochemical data indicate a northwestward increase in the terrigenous supply from distant sources as well as a deepening of, and an increase in distance from, the seafloor spreading center.

4) There were three successive inputs of illite, chlorite, mixed-layer clays, kaolinite, and some palygorskite during the late Maestrichtian. They probably are expressions of minor phases of the Late Cretaceous tectonic reaction of Atlantic margins to a major spreading stage, associated with the development of deep circulation, or they may correspond to fluctuations in sea level.

5) The Maestrichtian/Paleocene boundary is characterized by strong mineralogical and geochemical changes, indicative of volcanic influence and local subsidence at Site 525 and of continental planation and soil development at Site 527.

6) During the Paleocene a clay homogenization appears at all the sites, reflecting the subsidence of the 


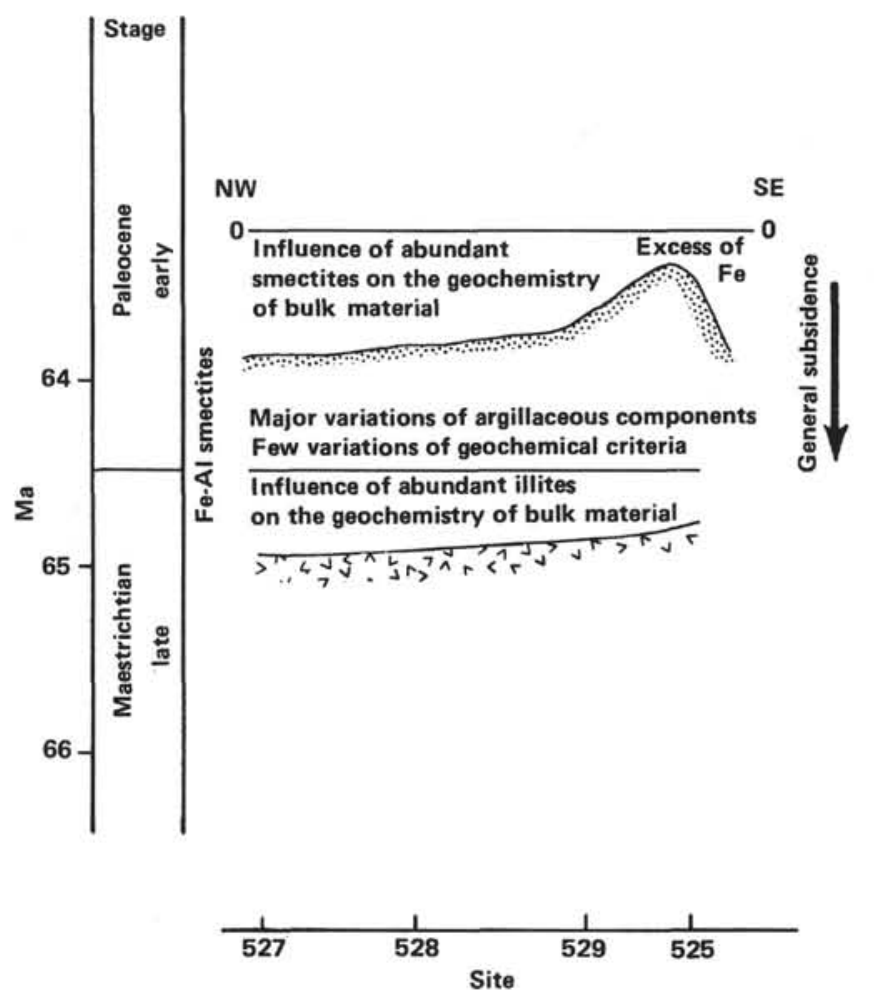

Figure 7. Relationship between bulk geochemistry and clay mineralogy at the Cretaceous/Tertiary boundary.

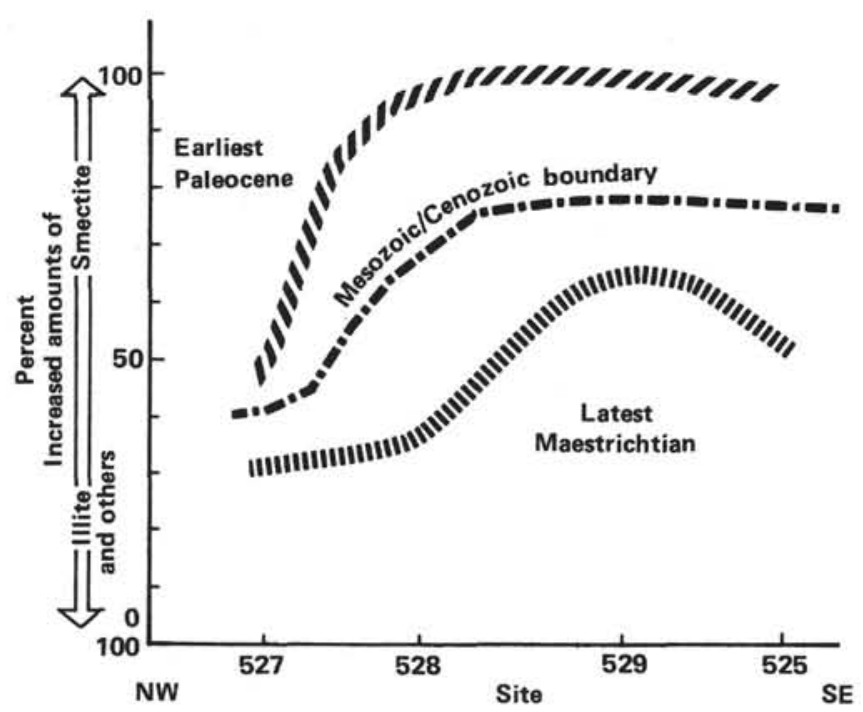

Figure 8. Relative variations of smectite and other clay minerals at the Maestrichtian/Paleocene boundary (one sample for each stage).

Walvis Ridge and the development of water masses exchanges. Subsidence, leading to the disappearance of subaerial volcanic rocks, becomes important during the late Paleocene, as expressed by the geochemistry. At the same time, on the adjacent continent, a morphological peneplanation develops with perimarine basins associated with a time of tectonic quiescence and transgressive environment.

\section{ACKNOWLEDGMENTS}

The financial support for this study was provided by CNEXO (France) through grant No. 80/6231 and by DGRST (grant No. 78/7/ 2941). J.-C. Sibuet, J. Mascle, P. Borella, and T. Moore reviewed the manuscript and helped us significantly to improve it. We gratefully acknowledge M. Bocquet, A.-M. Candillier, J. Carpentier, and F. Dujardin for technical assistance.

\section{REFERENCES}

Boström, K., Joensuu O., Valdes S., and Riera M., 1972. Geochemical history of South Atlantic Ocean sediments since Late Cretaceous. Mar. Geol., 12:85-121.

Boström, K., Peterson M. N., Joensuu O., and Fisher D., 1969. The origin of the aluminum poor ferromanganoan sediments in areas of high heat flow in the East Pacific Rise. Mar. Geol., 7:427-447.

Chamley, H., 1979. North Atlantic clay sedimentation and paleoenvironment since the Late Jurassic. In Talwani, M., Hay, W., and Ryan W. B. F. (Eds.), Deep Drilling Results in the Atlantic Ocean: Continental Margins and Paleoenvironment. Maurice Ewing Series: Washington (American Geophysical Union), 3:342-361. 1980. Clay sedimentation and paleoenvironment in the area of Daito Ridge (Northwest Philippine Sea) since the early Eocene. In Klein, G. deV. Kobayashi K., et al., Init. Repts. DSDP, 58: Washington (U.S. Govt. Printing Office), 683-693.

Chamley, H., and Bonnot-Courtois, C., 1981. Argiles authigènes et terrigènes de l'Atlantique et du Pacifique NW (Legs 11 et 58 DSDP): apport des terres rares. Oceanol. Acta, 4(2):229-238.

Chamley, H., and Robert, C., 1979. Late Cretaceous to Early Paleogene environmental evolution expressed by the Atlantic clay sedimentation. In Christensen, W. K., and Birkelung, T. (Eds.), Cretaceous/Tertiary Boundary Events Symposium (Vol. 2): Copenhagen (University of Copenhagen), 71-77.

Debrabant, P., and Foulon, J., 1979. Expression géochimique des variations du paléoenvironnement depuis le Jurassique supérieur sur les marges nord-atlantiques. Oceanol. Acta, 2:469-476.

Deer, W. A., Howie, R. A., and Zussman, J., 1962. Rock-forming minerals. Sheet Silicates (Vol. 3): London (Clowes and Sons).

Giblin, P., 1979. Minéralogie et géochimie de la limite Crétacé-Tertiaire dans quelques forages océaniques profonds. Th. 3ème cycle: Strasbourg, 115 p. typescript.

Hsü, J., 1980. Terrestrial catastrophe caused by cometary impact at the end of Cretaceous. Nature, 285(5762):201-203.

Maillot, H., 1980. Géochimie des sédiments crétacés et cénozoïques de la marge atlantique sud-orientale (Leg 40 DSDP). Rev. Géol. dyn. et géogr. phys., XXII:75-83.

Maillot, H., and Robert, C., 1980. Minéralogie et géochimie des sédiments crétacés et cénozoïques dans l'Océan Atlantique Sud (marge africaine, dorsale médio-atlantique). Bull. Soc. géol. France, 22: (7) $777-788$.

Mélières, F., 1978. X-ray mineralogy studies, Leg 41, Đeep Sea Drilling Project, Eastern North Atlantic Ocean. In Lancelot, Y., Seibold, E., et al., Init. Repts. DSDP, 41: Washington (U.S. Govt. Printing Office), 1065-1086.

Millot, G., 1964. Géologie des argiles: Paris (Masson).

Nathan, Y., and Flexer, A., 1977. Clinoptilolite, paragenesis and stratigraphy. Sedimentology, 24:845-855.

Paquet, H., 1969. Evolution géochimique des minéraux argileux dans les altérations et les sols des climats méditerranéens et tropicaux à saisons contrastées. Sci. Géol. Strasbourg, 30.

Robert, C., 1981. Santonian to Eocene palageogeographic evolution of the Rio Grande Rise (South Atlantic) deduced from clay-mineralogical data (DSDP Legs 3 and 39). Palaeogeogr., Palaeoclimat., Palaeoecol., 33:311-325.

Robert, C., Herbin, J.-P., Deroo, G., Giroud, d'Argoud G., and Chamley, H., 1979. L'Atlantique Sud au Crétacé d'après l'étude des minéraux argileux et de la matière organique (Legs 39 et 40 DSDP). Oceanologica Acta, 2:209-218.

Robert, C., and Maillot, H., in press. Paleoenvironmental significance of clay mineralogical and geochemical data, South-West Atlantic (DSDP Legs 36 and 71). In Ludwig, W. J., Krasheninnikov, V. A., et al., Init. Repts. DSDP, 71: Washington (U.S. Govt. Printing Office). 
Shaffer, F. R., in press. The origin of the Walvis Ridge: sediment/basalt compensation during crustal separation. Palaeogeogr., Palaeoclimat., Palaeoecol.

Trauth, N., 1977. Argiles évaporitiques dans la sédimentation carbonatée tertiaire. Bassins de Paris, de Mormoiron et de Salinelles (France); Jbel Ghassoul (Maroc). Sci. Géol. Strasbourg, 49.
Vail, P. R., Mitchum, R. M., Todd, R. G., Widmier, J. M., Thompson, S., III, Sangree, J. B., Bubb, J. N., and Hatlelid, W. G., 1977. Seismic stratigraphy and global changes of sea-level. Am. Assoc. Petrol. Geol., 29:49-212.

Weaver, C. E., and Beck, K. C., 1977. Miocene of the S-E United States: a model for chemical sedimentation in a peri-marine environment. Sediment. Geol., 17(1/2), spec. issue.

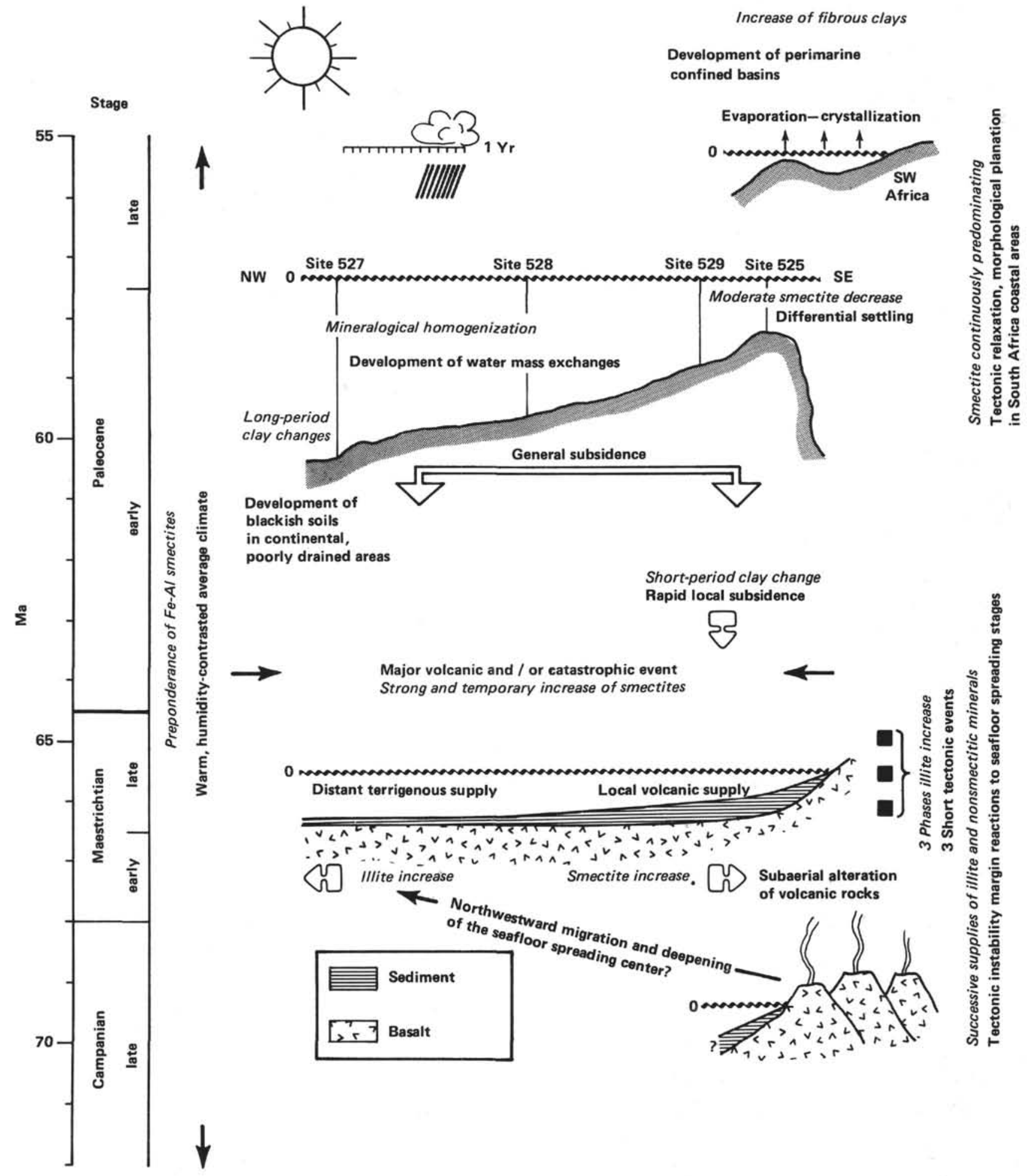

Figure 9. Interpretation (in roman type) of the paleogeographic evolution of the Walvis Ridge at the Cretaceous-Tertiary transition, from data (in italic type) on clay sedimentation. 



Plate 1. Electromicrographs of sediments overlying the uppermost basalts. '(Scale bar $=1 \mu \mathrm{m}$.) A-B. Sample 525A-52-5, 129 cm, late Campanian, volcanogenic smectite. C-D. Sample $527-38-4,79 \mathrm{~cm}$, late Maestrichtian, smectite and mixed-layer clays with blurred contours, illite and chlorite with sharp edges, palygorskite fibers. 


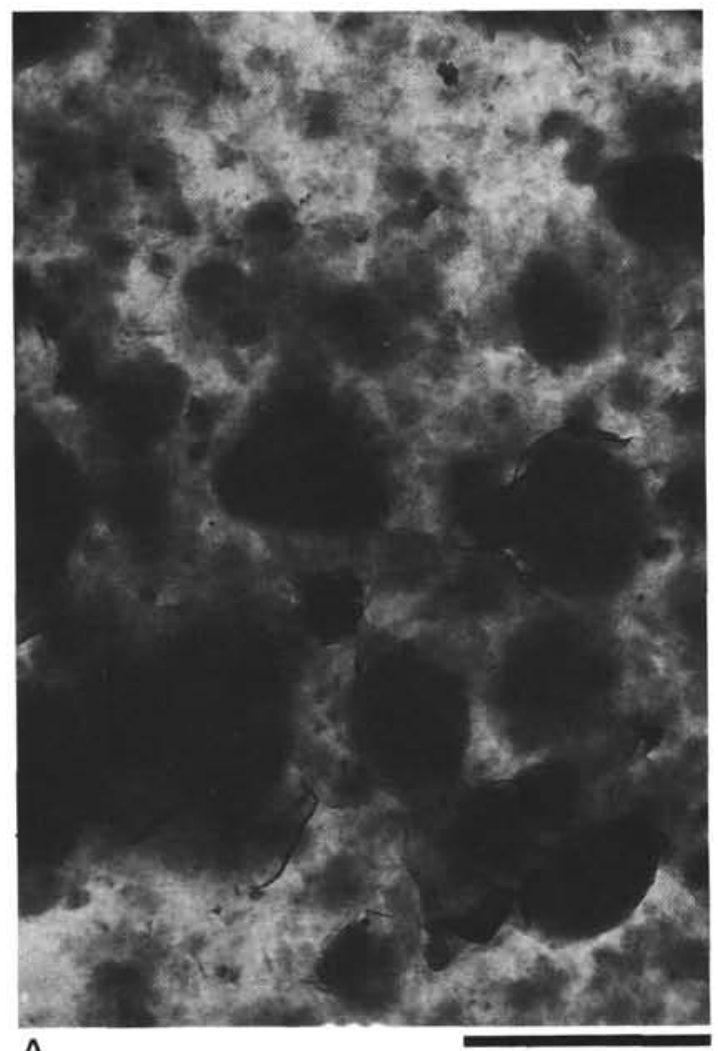

A

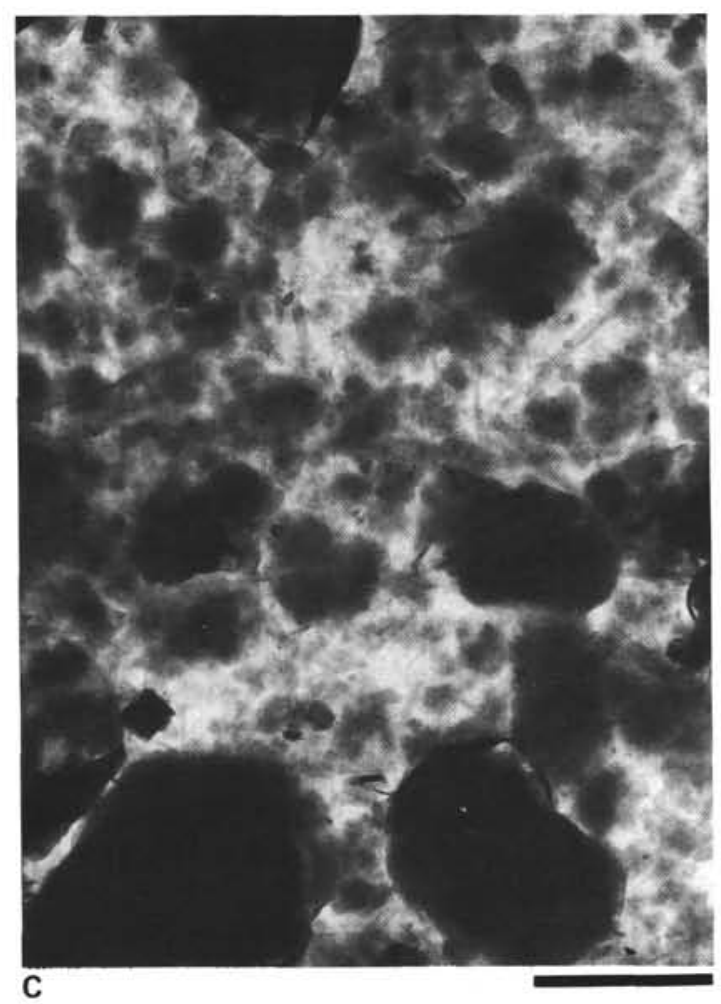

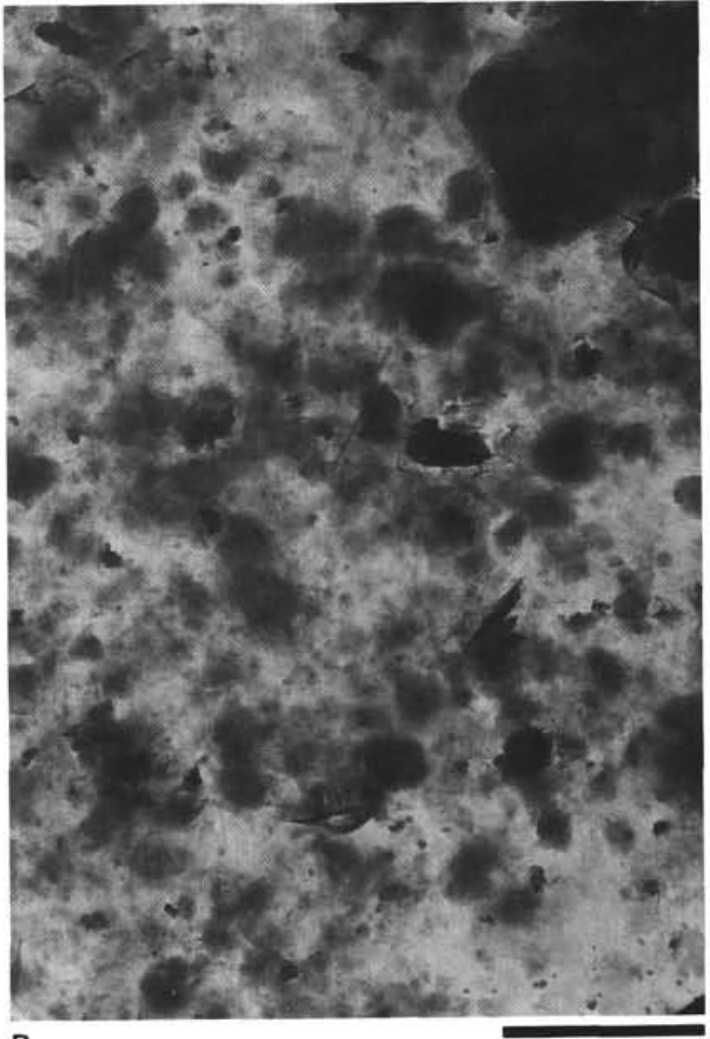

B

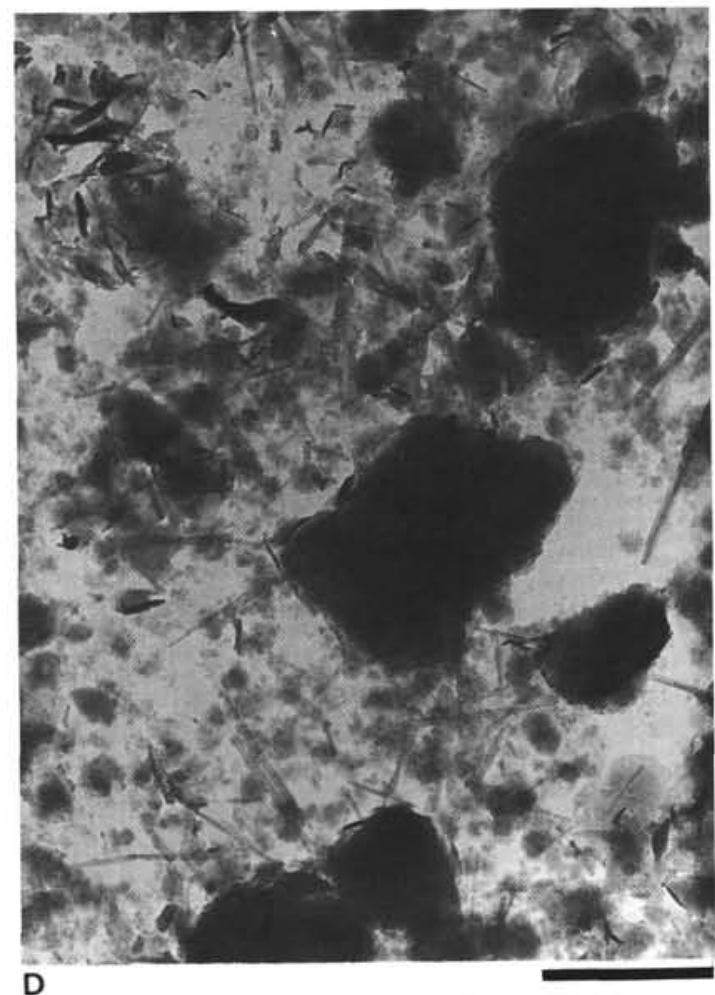

Plate 2. Electromicrographs, Cretaceous/Tertiary boundary. (Scale bar $=1 \mu \mathrm{m}$.) A-B. Lowermost Paleocene, preponderance of smectites (blurred contours), with rare associated minerals (traces of palygorskite at Site 528), (A) Sample 525A-39-5, $99 \mathrm{~cm}$, (B) Sample 525-31-5, 138 cm. C-D. Uppermost Maestrichtian, diversified clay assemblages: chlorite and illite with sharp edges, smectite and mixed-layer clays (blurred contours), palygorskite fibers (more abundant in Site 528), kaolinite hexagonal sheets (Site 525), (C) Sample 525A-40-3, 135 cm, (D) Sample 528-32-1, $101 \mathrm{~cm}$. 